\title{
INFLUENCE OF POWDER CHARACTERISTICS ON THE SPREADABILITY OF PRE-ALLOYED TUNGSTEN- CARBIDE COBALT
}

\author{
P. Govender ${ }^{1 *}$, D.C. Blaine ${ }^{1} \&$ N. Sacks ${ }^{2}$
}

\section{ARTICLE INFO}

\section{Article details}

Presented at the $22^{\text {nd }}$ Annual International Conference of the Rapid Product Development Association of South Africa (RAPDASA), held from 3-5 November 2021 in Pretoria, South Africa.

Available online

29 Nov 202

\section{Corresponding author}

18375391@sun.ac.za

\section{Author affiliations}

1 Department of Mechanical and Mechatronic Engineering, DSI-NRF Centre of Excellence in Strong Materials, Stellenbosch University, South Africa

2 Department of Industrial Engineering, DSI-NRF Centre of Excellence in Strong Materials, Stellenbosch University, South Africa

\section{ORCID® identifiers}

P. Govender

https://orcid.org/0000-0001-8337-091X

D.C. Blaine

https://orcid.org/0000-0001-8332-362X

N. Sacks

http: //orcid.org/ 0000-0001-7769-7588

DOI

http://dx.doi.org/10.7166/32-3-2664

\section{ABSTRACT}

With rising interest in additive manufacturing (AM) techniques, there is an increased focus on research that evaluates critical parameters that guide the selection of powders that are suitable for AM. One such parameter is a powder's spreadability, described by metrics such as powder bed density and percentage coverage. This study focused on three spray-dried WC-Co powders (two $12 \mathrm{wt} \%$ and one $17 \mathrm{wt} \% \mathrm{Co}$ ) and evaluated the influence of typical powder characteristics, such as particle size and shape, apparent density, and flow rate, on their spreadability. It was found that particle size distribution influenced the powder spreadability. Larger particles hindered the even spreading of powder over the base plate, resulting in low powder bed density and percentage coverage. This also correlated with the powders' apparent densities. The flow rate and angle of repose gave an indication of how cohesive the powders are. The more cohesive a powder, the poorer the spreadability, resulting in a lower powder bed density and percentage coverage.

\section{OPSOMMING}

Met toenemende belangstelling in toevoegingsvervaardiging tegnieke, is daar 'n groter fokus op navorsing wat kritieke parameters evalueer, vir die geskikte keuse van poeiers vir toevoegingsvervaardiging. Een so 'n parameter is ' $n$ poeier se verspreibaarheid, beskryf deur maatstawwe soos poeierbeddigtheid en persentasie dekking. Hierdie studie het op drie WCCo-poeiers (twee 12 gew.\% en een 17 gew.\% Co), wat deur 'n spuitdroging proses vervaardig word, gefokus; die invloed van tipiese poeierkenmerke, soos partikelgrootte en -vorm, massadigtheid en vloeitempo, op hul verspreibaarheid is geëvalueer. Daar is gevind dat partikel grootteverdeling die mate van poeier verspreibaarheid beïnvloed het. Groter partikels het die eweredige verspreiding van poeier oor die basisplaat belemmer. Dit het gelei tot lae poeierbeddigtheid en persentasie bedekkings. Dit het ook gekorreleer met die massadigthede van die poeiers. Die vloeitempo en natuurlike helling het 'n aanduiding gegee van hoe samehangend die poeiers is. Hoe meer samehangend ' $n$ poeier is, hoe slegter is die verspreiding, wat lei tot 'n laer poeierbeddigtheid en persentasie bedekking.

\section{I INTRODUCTION}

Cemented carbides are metal matrix composites in which metallic carbides, such as tungsten carbide (WC), titanium carbide $(\mathrm{TiC})$, or tantalum carbide $(\mathrm{TaC})$, act as reinforcing particles inside a metallic matrix, typically cobalt (Co)- or nickel (Ni)-based. The carbides provide high levels of strength and hardness as well as wear resistance, while the binder provides a high degree of toughness that counters the brittle nature of the carbides [1],[2]. They are traditionally produced via the press-and-sinter powder metallurgy (PM) technique [2]. The WC-Co composite is a common cemented carbide that is traditionally used to produce cutting inserts or high wear tool parts owing to its excellent combination of thermal stability and its high levels of hardness and toughness [1],[3]. 
Laser powder bed fusion (LPBF), an additive manufacturing (AM) technique, is a potential alternative to conventional production methods, offering advantages in reducing production time and improving the feasibility of manufacturing complex geometries [2],[3],[4],[5]. High-quality LPBF products depend on the use of powder that has suitable spreadability characteristics.

The aim of this study is to determine the link between typical powder characteristics and powder spreadability metrics, specifically for spray-dried WC-Co powders, at Co contents of 12 and 17 wt\%, respectively.

\section{MATERIALS AND METHODS}

\subsection{Raw material}

Three commercially available, spray-dried and agglomerated WC-Co powders, typically used for highvelocity oxygen fuel (HVOF) coating with varying Co content, were used for this study. Two of the powders were supplied by Praxair (1342 VM and 727-6) and contained $12 \mathrm{wt} \% \mathrm{Co}$, which varies in particle sizes, with the latter having a smaller particle size. The third powder was supplied by Kennametal (JetKote 117) and contained 17 wt\% Co. These are referred to as Powders 1, 2, and 3 respectively. Table 1 shows the compositions of the specified powders as provided by the suppliers.

Table 1: Powder composition

\begin{tabular}{|c|c|c|c|c|}
\hline Powder description & Formula & WC (wt\%) & Co (wt\%) & Other (wt\%) \\
\hline Powder 1 & WC-12Co & 82.5 & 11.72 & 5.77 \\
\hline Powder 2 & WC-12Co & 82.5 & 12 & 5.5 \\
\hline Powder 3 & WC-17Co & 77.8 & 17 & 5.2 \\
\hline
\end{tabular}

\subsection{Methodology}

The powders were initially characterised according to their particle size distribution and shape, determined through light scattering and scanning electron microscopy (SEM) techniques, respectively. Apparent density and flow rate were evaluated for all of the powders according to ASTM standards B212, B213, and B417. The angle of repose was also determined to view the flowability and cohesiveness of the powders. The variation in characteristics allows one to view which characteristics influence which spreadability metrics.

The spreadability metrics, the powder bed spread density (PBD), and the percentage coverage were measured using a custom-designed rig [6]. The PDB was measured by placing enough powder to cover the base plate of the spreadability rig on one edge of the base plate. Different layer heights were then used to spread the powder across the base plate. Excess powder was brushed off, and the powder that remained on the base plate was weighed to determine its mass. The volume was calculated based on the base plate area and the varying layer heights. The PBD over the base plate was assumed to be consistent for each layer height. The percentage coverage was determined with the same test, with just enough powder being placed on the base plate to cover it at various layer heights. This was determined by multiplying the apparent density by various volumes. The powder was spread, and an overhead image was captured. The image was converted to a black-and-white image through Matlab, and the number of dark pixels that were measured (the powder) was divided by the total number of pixels to determine the percentage coverage [6]. Figure 1 shows an example of the conversion process. The image on the left shows the original picture of powder spread on a base plate, while the image on the right is the image converted into black-andwhite. The wiper blade motion was from top to bottom, in correlation with the image. The transverse lines were caused by the motion of the wiper blade across the base plate. The resistance of the rod connecting to the blade caused a staggered motion while the blade moved across the blade plate.
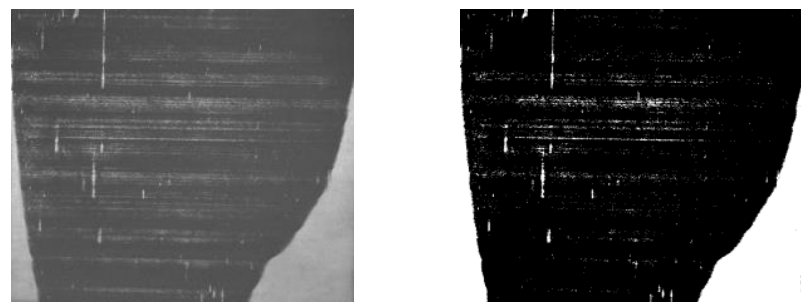

Figure 1: Example of percentage coverage conversion through Matlab (Powder 1 at $80 \mu \mathrm{m}$ layer height) 


\subsection{Initial characterisation}

Figure 2 shows the SEM imaging of the powders at low and high magnifications; the $100 \mu \mathrm{m}$ and $10 \mu \mathrm{m}$ scale bars are shown. Energy dispersive spectroscopy (EDS) analysis was performed to view the regions of the WC and Co compositions. Figure 3 shows the WC and Co regions, represented by the lighter and darker regions, respectively. Here it can be seen that the WC grains are the reinforcing material within the Co binder forming the matrix. All powders are spherical in nature, with agglomerates forming post-processing; powder 2 contains a few irregular-shaped particles. As one can see, powders 1 and 3 are similar in size, with a $14.9 \%$ difference in D90 particle size, while powder 2 is much smaller, with differences from powder 1 and powder 3 of $39.1 \%$ and $48.2 \%$ in D90 particle size, respectively, as shown in Table 2.

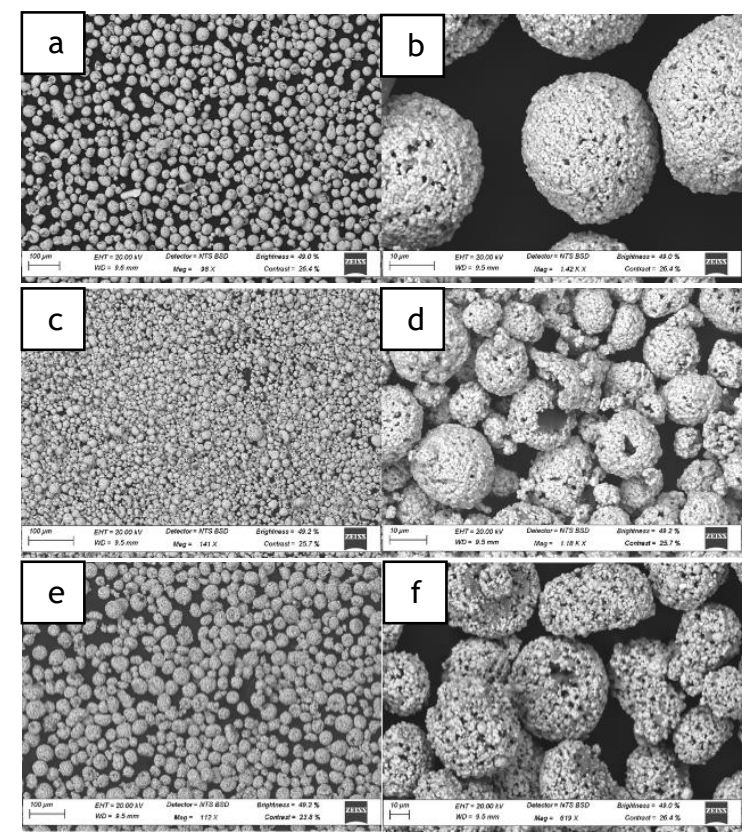

Figure 2: SEM images of Powder 1 (' $a$ ' and ' $b$ '), Powder 2 ('c' and ' $d$ ') and Powder 3 ('e' and 'f')

Table 2: Powder particle sizes

\begin{tabular}{|l|c|c|c|}
\hline & $\mathrm{D} 10(\mu \mathrm{m})$ & $\mathrm{D50}(\mu \mathrm{m})$ & $\mathrm{D} 90(\mu \mathrm{m})$ \\
\hline Powder 1 & 21.50 & 31.94 & 43.05 \\
\hline Powder 2 & 8.66 & 16.46 & 26.22 \\
\hline Powder 3 & 24.96 & 36.96 & 50.59 \\
\hline
\end{tabular}

The powder characteristics, apparent density and flow rate, are listed in Table 3. ASTM standards B212 and B417 were used to characterise the apparent density of free flowing and non-free flowing powders, respectively. ASTM standard B213 was used to characterise the flow rate. It was observed that powder 2 did not flow, and thus it was expected that the spreadability results would be affected by the restricted flow of the powder, and would be visible in either or both spreadability metrics. Baitimerov et al. [6] showed that the factors that influence apparent density also influence spreadability. Powders with smaller D10 and D50 particle sizes tend to have a higher apparent density, while very fine powders are influenced by inter-particle forces that result in high cohesive forces, leading to a poorer flow rate and spreadability. The presence of irregularly shaped particles also decreases apparent density by hindering the powders' ability to pack.

The angle of repose (AoR) is defined as the angle of inclination of the free surface to the horizontal of a bulk solid heap, which is a criterion for the flowability of a powder (Table 4). This test is performed by allowing powder to flow freely though a funnel at a set height onto a flat surface. The angle that the powder makes once a heap is formed at a certain height or diameter is known as the angle of repose. 
Table 3: Powder properties: Apparent density and flow rate

\begin{tabular}{|c|c|c|c|c|}
\hline & $\begin{array}{c}\text { Apparent } \\
\text { density } \\
\left(\mathrm{g} / \mathrm{cm}^{3}\right)\end{array}$ & Mean & $\begin{array}{l}\text { Flow } \\
\text { rate } \\
(\mathrm{s} / 50 \mathrm{~g})\end{array}$ & Mean \\
\hline \multirow{3}{*}{ Powder 1} & 5,41 & \multirow{3}{*}{$5,39 \pm 0.014$} & 15,56 & \multirow{3}{*}{$\begin{array}{c}14,18 \pm \\
0.978\end{array}$} \\
\hline & 5,38 & & 13,58 & \\
\hline & 5,38 & & 13,40 & \\
\hline \multirow{3}{*}{ Powder 2} & 4,95 & \multirow{3}{*}{$4,96 \pm 0.005$} & Does & \multirow{3}{*}{$\begin{array}{l}\text { Does not } \\
\text { flow }\end{array}$} \\
\hline & 4,96 & & not & \\
\hline & 4,96 & & flow & \\
\hline \multirow{3}{*}{ Powder 3} & 3,97 & \multirow{3}{*}{$3,98 \pm 0.003$} & 22,28 & \multirow{3}{*}{$21,73 \pm 0.534$} \\
\hline & 3,98 & & 21,92 & \\
\hline & 3,98 & & 21,01 & \\
\hline
\end{tabular}

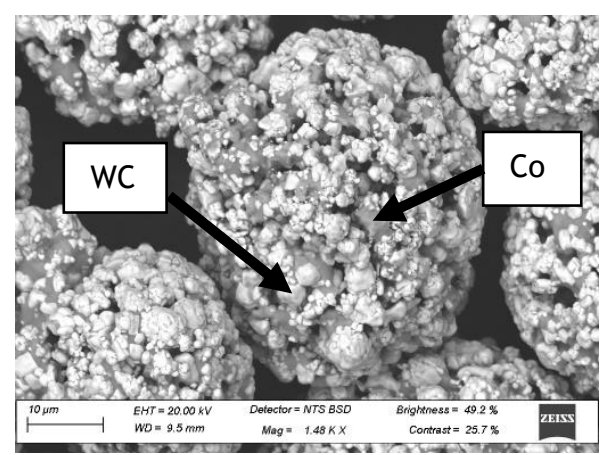

Figure 3: WC-Co particle

Figure 4 shows the AoR for powders 1-3. Simek et al. [7] relate the degree of flowability to the AoR of a powder; these relationships were used to describe the powder flow in this investigation. Powders 1 and 3 had an excellent flow with respect to the angle of repose, while powder 2 was described as good, as listed in Table 4. A lower AoR generally leads to better flowability.

Table 4: Flow property according to the respective angles of repose [7]

\begin{tabular}{|c|c|c|}
\hline & $\begin{array}{r}\text { Average angle of } \\
\text { repose }\left(^{\circ}\right)\end{array}$ & $\begin{array}{c}\text { Flow } \\
\text { property }\end{array}$ \\
\hline Powder 1 & 30 & Excellent \\
\hline Powder 2 & 35 & Good \\
\hline Powder 3 & 26.5 & Excellent \\
\hline
\end{tabular}

\subsection{Spreadability results}

\subsubsection{Powder bed density}

The PBD was initially tested on one powder at various layer heights to confirm the consistency of the results. The average of five tests was reported for each layer height, with the average of all layer heights then stated to find an average PBD. These results are listed in Table 5. The PBD for all of the powders can be seen to have been lower than those of the initially measured apparent densities. Powder 1 had the closest PBD to apparent density, with a $16.9 \%$ difference.

Table 5: Powder bed density

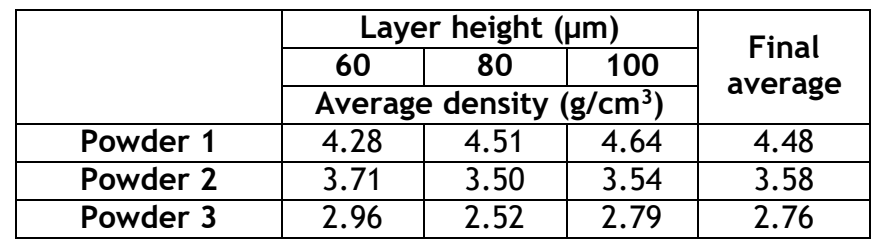

Powders 2 and 3 had a much lower PBD than their reported apparent densities, with differences of $27.9 \%$ and $30.6 \%$ respectively. Powder 2's resistance to flow would result in less powder being spread over the base plate at each layer height. This can also be attributed to the irregularly shaped particles, which 
increase particle friction and so decrease the flowability. Similar results were identified by Snow et al. [9]. Powder 3 had larger particles than powder 1; and they were more resistant to flow at the set layer heights than those of powder 1. Fewer powder particles could be spread, resulting in a lower PBD. This phenomenon was recorded by Cordova et al. [11], who also noted that large powder particles or agglomeration block further spreadability from taking place. This creates lines on the base plate where little to no powder is present, which in turn results in less material; the lower PBD can be attributed to these lines or tracks where no powder is present.

The percentage coverage was determined at layer heights of 40,60 , and $80 \mu \mathrm{m}$. The results of this experiment are presented in Table 6. By looking at the particle size distributions of each powder and relating them to the percentage coverage, we found that most of the particles (D90) were smaller than 51 $\mu \mathrm{m}$. It stands to reason that, at the layer height of $40 \mu \mathrm{m}$, we saw a very low percentage coverage, as only $50 \%$ of the powder particles in powders 1 and 3 were smaller than $40 \mu \mathrm{m}$. Powder 1 was the only powder that was seen to increase its percentage coverage as the layer height was increased. This might have been because powder 1 had a smaller particle size than powder 3 , and better flow properties than powders 2 and $3.90 \%$ of the powder particles in powder 1 are smaller than $44 \mu \mathrm{m}$, allowing better spreadability at layer heights of 60 and $80 \mu \mathrm{m}$.

\subsubsection{Percentage coverage}

The percentage coverage was determined at layer heights of 40,60 , and $80 \mu \mathrm{m}$. The results of this experiment are presented in Table 6. By looking at the particle size distributions of each powder and relating them to the percentage coverage, we found that most of the particles (D90) were smaller than 51 $\mu \mathrm{m}$. It stands to reason that, at the layer height of $40 \mu \mathrm{m}$, we saw a very low percentage coverage, as only $50 \%$ of the powders were smaller than $40 \mu \mathrm{m}$ in powders 1 and 3 . Powder 1 was the only powder that was seen to increase its percentage coverage as the layer heigh was increased. This might have been because powder 1 had a smaller particle size than powder 3 , and better flow properties than powders 2 and 3 . Powder 1 had $90 \%$ of its powders below $44 \mu \mathrm{m}$, allowing a better flow at 60 and $80 \mu \mathrm{m}$.

Powder 2 had a lower percentage coverage at both the 60 and $80 \mu \mathrm{m}$ layer heights than the other powders. Even though the powder particles were much smaller than the respective layer heights, as reported in Table 3 , the powder did not flow, resulting in a low percentage coverage at each layer height. Powder 2 was also the most cohesive powder to be tested. Hulme-Smith et al. [12] also recorded poor percentage coverage results, less than $40 \%$ at $50 \mu \mathrm{m}$ layer height, for a very cohesive powder (it did not flow in their flow rate test), with a sub-22 $\mu \mathrm{m}$ particle size distribution; additionally, no indication of increase in percentage coverages was observed with an increased in the layer height.

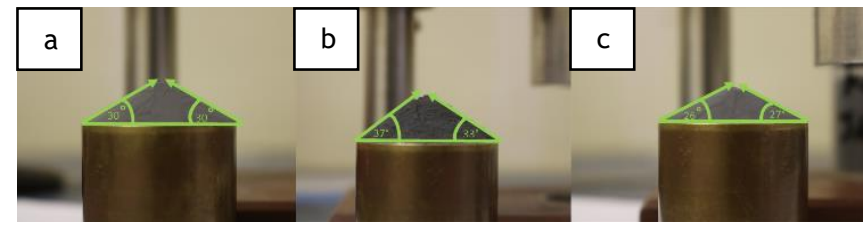

Figure 4: Angle of repose for (a) powder 1, (b) powder 2 and (c) powder 3

Table 6: Percentage coverage

\begin{tabular}{|c|c|c|c|}
\hline \multirow{2}{*}{} & \multicolumn{3}{|c|}{ Layer height $(\mu \mathrm{m})$} \\
\cline { 2 - 4 } & $\mathbf{4 0}$ & $\mathbf{6 0}$ & $\mathbf{8 0}$ \\
\cline { 2 - 4 } & \multicolumn{3}{|c|}{ Percentage coverage } \\
\hline Powder 1 & 52.30 & 80.94 & 87.55 \\
\hline Powder 2 & 52.01 & 66.81 & 35.49 \\
\hline Powder 3 & 55.61 & 82.03 & 56.22 \\
\hline
\end{tabular}

\section{CONCLUSION}

The powder characteristics of three WC-Co powders with varying Co content were evaluated and correlated to each powder's spreadability. It was found that powders with lower AoR values have a higher percentage coverage. This finding related to powders 1 and 3, which also showed better flow rates; improved flow contributes to improved spreadability. Powder 2 did not flow, and therefore spreadability was restricted, which is attributed to the finer particle size distribution and the irregularly shaped particles. This powder showed the lowest percentage coverage. The angle of repose was the highest for powder 2 , which correlates 
to its reduced spreadability. It was observed that powders 2 and 3 both had a difference of around $30 \%$ between PBD and apparent density. The high cohesive forces in Powder 1 could be a contributing factor; this is supported by the lack of flow and the slower flow rate for powders 2 and 3, respectively. Powders 2 and 3 had a lower percentage coverage and PBD than Powder 1, as well as lower apparent densities. Powder 1 had smaller particles than powder 3, yet powder 2 had restricted flow properties, which resulted in a lower apparent density than powder 1 .

The main contributing factors to the efficiency of spreadability are cohesiveness and particle size distribution; these correlate to powder characteristics, such as the angle of repose, apparent density and flow rate. Further experimentation is needed to quantify the spreadability metrics and to identify which parameters influence which metrics

\section{ACKNOWLEDGEMENT}

The authors wish to acknowledge the financial support received from the Department of Science and Innovation and the National Research Foundation of South Africa (Grant Nos: 41292 and 129313). The opinions expressed and conclusions arrived at are those of the author/s, and are not necessarily to be attributed to the Centre of Excellence in Strong Materials.

\section{REFERENCES}

[1] W.D. Schubert, E. Lasser, and W. Bohlke, “Cemented carbides: A success story," ITIA Newsletter, June 2010, available from: www.itia.info [Accessed 4 June 2021]

[2] A.G.P. da Silva, W.D. Schubert, and B. Lux, "The role of the binder phase in the WC-Co sintering," Materials Research, vol. 4 no. 2, pp. 59-62, 2001.

[3] S. Kumar, "Manufacturing of WC-Co moulds using SLS machine," J. Mat. Proc. Tech., vol. 209, No 8, pp. 38403848, 2009.

[4] N. Ku, J.J. Pittari, S. Kilczewski, and A. Kudzal, "Additive manufacturing of cemented tungsten carbide with a cobalt-free alloy binder by selective laser melting for high-hardness applications," JOM, vol. 71, No. 4, pp. 15351542, 2019.

[5] D. Bricin, and A. Kriz, "Processability of WC-Co powder mixtures using SLM additive technology," MM Science Journal, pp. 2939-2945,2019 doi:10.17973/MMSJ.2019_06_2018115

[6] B.S. Parker, "Blending of powders for in-situ alloying of Ti-6Al-4V laser powder bed fusion," MEng thesis, Stellenbosch University, South Africa, 2021, https://scholar.sun.ac.za/handle/10019.1/110122

[7] R. Baitimerov, P. Lykov, D. Zherebtsov, L. Radionova, A. Shultc, and G. Prashanth, 2018, "Influence of powder characteristics on processability of AlSi12 alloy fabricated by selective laser melting," Materials, vol 11, no. 5, 742, pp. 1-14, 2018, doi:10.3390/ma11050742

[8] H. Kalman, 2021, "Quantification of mechanisms governing the angle of repose, angle of tilting, and Hausner ratio to estimate the flowability of particulate materials," Powder Technology, vol. 382, pp. 573-593, 2021, doi.org/10.1016/j.powtec.2021.01.012

[9] M. Simek, V. Grunwaldova, and B. Kratochvil, "Comparison of compression and material properties of differently shaped and sized paracetamols," KONA Powder and Particle Journal, vol 34, pp. 197-206, 2016, doi:10.14356/kona.2017003

[10] Z. Snow, R. Martukanitz, and S. Joshi, "On the development of powder spreadability metrics and feedstock requirements for powder bed fusion additive manufacturing," Additive Manufacturing, vol 28 No 6, pp. 78-86, 2019.

[11] L. Cordova, T. Bor, M. de Smith, M. Campos, and T. Tinga, "Measuring the spreadability of pre-treated and moisturized powders for laser powder bed fusion," Additive Manufacturing, vol. 32 No 91, 101082, 2020.

[12] C.N. Hulme-Smith, V. Hari, and P. Mellin, "Spreadability testing of powder for additive manufacturing," Berg Huettenmaenn Monatsh, vol. 166 no.1, pp. 9-13, 2021. 